\title{
A Probability Model For Earnings Restatement
}

Abdoulaye Dabo, Colorado College, USA

Judith A. Laux, Colorado College, USA

\begin{abstract}
Given their prevalence in recent years, earnings management and financial restatements have been at the center of much of the discussion surrounding corporate malfeasance. This study builds a probability model for predicting the likelihood of earnings restatements by analyzing the trends in and the deviations from the industry averages of the return on assets, accounts receivable turnover, net profit margin, and operating cash flow to net income measures. Data are obtained for a sample of 104 firms (restating as well as non-restating) for the 2000 to 2001 period. The results suggest that deviations from the industry average of the accounts receivable turnover and the variability in the cash flow to net income provide good barometers for detecting fraudulent accounting. Potential restating firms have higher accounts receivable turnover rates than their industry counterparts and downward trends in their cash flow to net income, so an increase (decrease) in the accounts receivable turnover (operating cash flow to net income) significantly increases the likelihood of a restatement, at least in the current study.
\end{abstract}

Keywords: Earnings Management; Predictability of Earnings; Cash Flow; Financial Ratios

\section{INTRODUCTION}

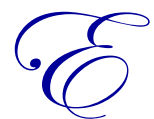

arnings restatements pervaded the headlines of the first decade of this century. In 2000, Waste Management was required to restate its earnings, ultimately decreasing them by almost $\$ 1$ billion. In December of 2001, Enron, a Houston-based American Energy company, filed for bankruptcy. The energy giant, valued at $\$ 70$ billion in the years prior to filing for Chapter 11, was actually only worth only $\$ 30$ billion. WorldCom's $\$ 40$ billion merger with MCI in 1999 was the largest in corporate history at the time, and WorldCom appeared to be one of the greatest corporate success stories ever. However, in 2002, WorldCom filed for a $\$ 101.9$ billion bankruptcy. In the court filing, the Securities and Exchange Commission said WorldCom admitted that it had concealed over $\$ 9$ billion in expenses, all of which were converted into fraudulent profit. WorldCom's total market value went from $\$ 120$ billion to almost nothing. Also in 2002, Xerox Corp inflated revenue by almost $\$ 1.9$ billion over a five-year period through misreporting the timing and makeup of equipment sales. In 2003, Nortel announced that its net income for the year was really half of what it had originally reported [Albrecht et al., 2008, pp. 186-187]. Stories such as these provide examples of one of the most common corporate practices over the past 15 or so years - earnings management, a controversial topic that drives the current study.

Why does egregious earnings management occur? In pricing securities, analysts weigh a firm's performance against an analyst-derived standard, and sometimes, in an effort to buoy up stock prices, managers engage in extreme or even fraudulent accounting to mask poor economic performance and mislead investors and creditors. Through earnings management, financial ratios and cash flows are manipulated and their accuracy altered. Consequently, industry comparisons and the variability of a given ratio over time can help illuminate troublesome items, a predictive relationship tested in the current study. The theoretical justification for such an investigation is clear. If managers manipulate earnings, they can portray a surreal economic performance, violating accounting standards and making markets inefficient. Investors base their decisions on past, present and future cash flows, and earnings management can mislead investors about those cash flows. Furthermore, the marketplace reacts negatively to the announcement of earnings restatements, and the SEC doles out heavy sanctions. 
The purpose of this study is to analyze the usefulness of financial ratios such as net profit margin, accounts receivable turnover, the rate of return on assets and a common proxy for earnings management, the cash flow to income ratio, to predict earnings restatement. By looking at the variability in these measures over a two-year period and comparing it to the industry average, we build a probability model to predict when earnings restatement is likely to occur. This study addresses three major questions: Is the variability in these financial ratios significant in the years prior to restatement? Are the differences between the ratios and the industry averages significant? Can we use these financial ratios to generate a powerful model for predicting earnings restatement?

The next part of this study reviews the empirical literature that investigates the importance of financial ratios and cash flow measures for predictive purposes. Later sections present our empirical study, including the data, methodology, results and analysis. We also note limitations and offer concluding remarks.

\section{A BRIEF REVIEW OF THE LITERATURE}

Much literature investigates the predictive ability of accounting information, including its usefulness in gauging future stock value, earnings restatement, earnings manipulation, and a firm's potential for bankruptcy. We cover only a portion of the literature to set the stage for our investigation. Fraser and Ormiston [2010] acknowledge the general importance of financial ratios as well as cash flows. In The Analysis of Financial Statements, they assert that financial ratios and cash flow information can serve as screening devices, indicating areas of potential growth and weakness and revealing matters that need further investigation. Moreover, Sloan [1996, as cited in Dechow and Skinner, 2000, p. 246], defines high-quality earnings as earnings comprised primarily of operating cash flows, and low-quality earnings as earnings heavily influenced by accruals. Thus, the financial ratios selected for this study (which are linked to accruals) and the cash flow to net income ratio are likely to provide good measures of the quality of earnings and be helpful in detecting fraudulent earnings management.

Richardson, Tuna and $\mathrm{Wu}$ [2002] attempt to predict earnings restatements, computing a probability model based primarily on changes in accruals pre-and post-restatement. They find that information about accruals is useful in predicting the earnings management behavior of restatement firms. They also find that restatement firms report larger accruals at the time as a result of financial manipulation compared to non-restatement firms. Even though these findings do not specifically mention financial ratios or cash flow, accruals do play a significant role in determining cash flow, net profit margin, account receivables turnover and return on assets, and thus it is safe to assert that information on these could help predict the probability of restatement.

A widely cited article by Bergstresser [2008] offers a good review of the literature relating earnings manipulation to managerial compensation. Their study, like many of the articles they summarize, suggests a propensity for managers "to exploit their discretion in reporting earnings" when their compensation relies heavily on earnings; managers then often "cash in" by exercising options and unloading shares after manipulating those reported earnings [p. 528]. The importance of financial ratios and cash flow to predict firm success becomes evident in Qiang and Farber's 2008 study on the complex relationships among earnings restatement, executive compensation and firm performance. The authors establish that improved operating performance follows a reduction in optionbased compensation. Also, they find that, compared to control firms, restatement firms that reduce their CEO's option-based compensation, on average, experience an increase in return on assets (ROA) of 2.1 percent in the first year and 5.6 percent in the first two years after this reduction. Furthermore, a significant improvement in operating performance due to the reduction in stock volatility follows the reduction in option-based compensation in this sample. In short, this study offers support for our selection of the ROA measure.

In investigating the W.T. Grant Company bankruptcy, Largay and Stickney [1980] found that all profitability, turnover and liquidity ratios had trended downward over the ten years prior to bankruptcy. Additionally, W.T. Grant did not generate any cash internally over that same decade, and a poor correlation existed between working capital provided by operations and cash flow from operating activities. These findings infer two things for the current study: 1) financial ratios measured in the years prior to restatement are likely to either trend upwards or downwards, and 2) cash flow from operating activities is a good predictor of future performance. In support of this, Bowen, Burgstahler and Daley [1986] investigate the relationship between earnings and various 
measures of cash flow and find that traditional measures of cash flow (e.g., net income plus depreciation and amortization, and working capital from operations) are highly correlated with earnings.

Research on the prediction of firm failure using accounting information started in the second half of the $19^{\text {th }}$ century and intensified in the second half of the $20^{\text {th }}$ century; the methodological rigor has improved substantially since the late sixties, and the practical interest has increased significantly. Altman [1968], in an attempt to assess the ability of ratio analysis to predict bankruptcy, combined financial ratios in a discriminant analysis. He found that ratios, if analyzed within a multivariate framework, take on greater statistical significance than the common technique of sequential ratio comparison. Altman's discriminant ratio model proved extremely accurate, predicting bankruptcy correctly in 94 percent of the initial sample of firms. Furthermore, the discriminant function was accurate in several secondary samples introduced to test the reliability of the model. The importance of ratio analysis to assess risk is again highlighted by Altman and Sabato [2007]. Gathering data on American SMEs (small and medium enterprises), Altman and Sabato analyze a complete set of financial ratios, carefully exploring their characteristics. By use of well-known statistical techniques, five financial ratios (profit/total assets, quick assets/current assets, net cash/net worth, change in net worth and change in retained earnings) are found in combination to be the best predictors of SME default. Building on the research on the relationship between risk and ratio analysis, Altman, Sabato and Wilson [2008] expand the credit risk model for SMEs and conclude that the inclusion of qualitative variables as predictors of company failure significantly improve the model's accuracy.

Beaver [1966, as cited in Aquino, 2010, p.145] uses a classification test to estimate the error rates potential creditors would experience if they classified firms as failed or not failed on the basis of different accounting ratios considered one at a time (univariate analysis). In his model, the cash flow to total debt and net income to total assets turn out to be the best predictors of corporate failure. The importance of financial ratios is once again emphasized by Davis and Peles [1993] who show that control of net operating income to sales (NOI) ratios over a 19- year period is correlated with the actual NOI ratio value in the twentieth year. This implies that the past values of financial ratios are good predictors of future firm performance. In fact, the variability in the income to sales ratio is a commonly used proxy for over-statement. Finally, Ohlson [1980], applying a methodology of conditional logit analysis, finds that total liabilities/total assets, net income/total assets, and working capital/total assets are significant in assessing the probability of bankruptcy.

These studies specifically explore the trends that surround pre-and post-bankruptcy and, in some cases, preand post-earnings restatement. Even though some of the works cited in this section primarily address bankruptcy, a strong relationship between ratio and cash flow analysis and earnings restatement is evident. Debt covenants sometimes invite earnings management to avoid violation when times are tough — often a prelude to bankruptcy. Even though ratio analysis and cash flow information have limitations, they are still relatively trustworthy indicators of future outcomes. The majority of these studies suggest that financial ratios and cash flows can be good predictors of firm failure or corporate earnings restatement, the subject of the current investigation.

\section{DATA AND METHODOLOGY}

As highlighted by the literature review above, Largay and Stickney, while investigating the W.T. Grant Company bankruptcy, found that some financial ratios trended down in the years prior to the declaration of bankruptcy. As with bankruptcy, earnings restatement can be the fruit of false wealth; this is the reason we choose to measure the variability and deviation from industry counterparts of the chosen financial ratios to capture their trends before restatement is required. Also as emphasized by Sloan [1996], high-quality earnings are comprised primarily of cash flows, and low-quality earnings rely on accruals. Given that the return on assets (ROA) and net profit margin (NPM) incorporate accruals in their computation, that accounts receivable are an asset, and that the cash flow to net income ratio (CFNI) incorporates cash flows, we hypothesize that these ratios will demonstrate strong predictive power regarding the quality of earnings in general and the likelihood of a restatement in particular.

A low return on assets indicates that earnings are relatively low given the level of available assets. A low net profit margin ratio can be an indicator about a firm's inability to efficiently monitor the costs of production. Also, a low or decreasing accounts receivable turnover ratio and a decreasing cash flow to net income can be signals about collection problems. In the case of an earnings restatement, a firm is required to correct previously published 
figures. As we mentioned earlier in this study, a major cause for earnings restatement is earnings management. An increase from one year to another or a relatively high level (when compared to the industry average) in the return on assets, accounts receivable turnover, and net profit margin will make a firm look more profitable and safe in the eyes of investors and creditors. The operating cash flow to net income ratio should remain fairly stable from year to year, and a significant decrease in the ratio indicates that accounting assumptions are instrumental in inflating reported net income. Thus, it makes intuitive sense to assume that the return on assets, net profit margin, and accounts receivable turnover rate will trend upwards, and operating cash flow to net income will trend downwards, in the years prior to restatement.

Mergent Online provides the input to compute the industry averages for the financial ratios. Industries are defined using the SIC codes of the companies in the sample. We obtain the net profit margin by dividing the net income by revenues. Moreover, we calculate the return on assets ratio as the net income divided by total assets. Sales are divided by accounts receivable to get the turnover. And finally, we obtain the cash flow to net income ratio by dividing the cash flows from operating activities by the net income.

The list of companies used for the statistical models in this study was obtained from the Government Accounting Office, Wilshire 5000, and the Russell 3000. These three sources provided access to restating as well as non-restating firms. Using the GAO's listing of financial restatement announcements in 2002 identified as having been made because of revenue recognition, cost or expense treatment, asset or inventory restructuring, acquisition or merger, classification issues, and changes in securities methods, the sampling process generated a list of 151 companies required to restate their earnings. [The list of companies is available from the authors.]

Similar to Richardson, Tuna, and Wu [2002], the goal of this study is to build a probability model using cash flows as well as financial ratios to predict the likelihood that a firm will be required to restate its earnings. Richardson, $\mathrm{Wu}$ and Tuna build a probability model as follows:

$R E S T A T E=\gamma_{0}+\gamma_{1} T A C C t+v_{t+1}$

where RESTATE is an indicator variable equal to one if the firm is a restatement firm and zero otherwise. This is a logit probability model that predicts the change in the likelihood of a restatement with a unit change in $T A C C_{t} .{ }^{1}$ Also, Ohlson [1980] uses conditional logit analysis to build a predictor model for bankruptcy. As a result, the current study's models are based on these previous studies dealing with bankruptcy and earnings restatement. Our models take the following form:

$$
\begin{aligned}
& \text { Restatement }_{1}=a_{0}+a_{1} \text { ROA }_{\text {variability }}+a_{2} \text { DevROA }_{t-1}+a_{3} \text { DevROA }_{t-2}+t \\
& \text { Restatement }_{2}=b_{0}+b_{1} \text { ART }_{\text {variability }}+b_{2} \text { DevART }_{t-1}+b_{3} \operatorname{DevART}_{t-2}+u \\
& \text { Restatement }_{3}=c_{0}+c_{1} N P M_{\text {variability }}+c_{2} \text { DevNPM }_{t-1}+c_{3} \text { DevNPM }_{t-2}+v \\
& \text { Restatement }_{4}=d_{0}+d_{1} \text { CFNI }_{\text {variability }}+d_{2} \text { DevCFNI }_{t-1}+d_{3} \text { DevCFNI }_{t-2}+w
\end{aligned}
$$

where, Restatement ${ }_{1}$ is the binary dependent variable, $\mathrm{ROA}_{\text {variability }}$ is the change in the return on assets ratio between 2000 and 2001, DevROA t $-1_{1}$ is the deviation of the return on assets ratio from the industry average in year 2001, DevROA $_{t-2}$ is the deviation of the return on assets ratio from the industry average in year 2000; through $\mathrm{w}$

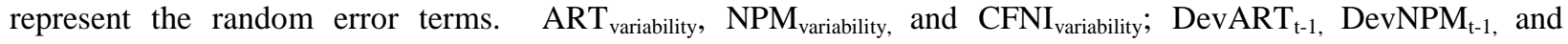

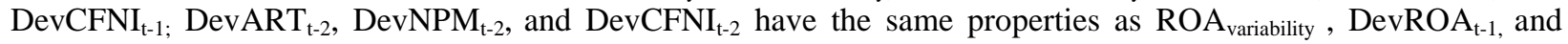
DevROA $_{t-2}$, respectively.

\footnotetext{
${ }^{1} T A C C_{t}$ measures total accruals and addresses the change in the current operating assets and current operating liabilities, the change in the non-current operating assets and liabilities, and the change in the short-term investments, long-term investments and financial liabilities.
} 
For the list of restating companies, we used the Wilshire 5000 to generate a list of non- restating companies as a matched sample, using industry and size. The Wilshire 5000 was used instead of the S\&P 500, because this did not unduly limit the size of our sample. Given that the majority of the restating firms are smaller in size than S\&P 500 firms, choosing only from the S\&P 500 would have omitted smaller firms and, most certainly, significantly altered the results. The sample of restating as well as non-restating firms obtained from the GAO and the Wilshire was then cross checked with the Russell 3000 list found on Mergent Online. To be retained in the final sample, a firm must have been founded prior to 1999, with financial statements for both 2000 and 2001, to generate the return on assets ratio, the accounts receivable turnover ratio, the net profit margin, and the cash flow to net income ratio for both 2000 and 2001. Because of these criteria, the sample size was further reduced to a total of 104 firms (52 restating and 52 non-restating). [The restricted sample also is available from the authors.]

The data will help test our hypotheses that the return on assets, accounts receivable turnover, and net profit margin will vary positively and the cash flow to net income negatively in the two years prior to restatement. Also the data will help test our hypothesis that these ratios differ significantly from the industry averages.

\section{RESULTS AND ANALYSIS}

As Table 1 and Table 2 illustrate, only the deviation from the industry average of the accounts receivable turnover and the variability in the operating cash flow to net income were statistically significant at the 5 percent level and 1 percent level, respectively. The return on assets and the net profit margin may not have been significant in this model because of the short time period analyzed and because the cash flow to net income already had captured some of the net profit margin's effects. Also, the two-sample t-test for equal means suggests that the samples of restating and non-restating firms are very similar for the ROA, ART, and NPM, and this may further hinder the outcome; when outliers within 3.0, 2.5 and 2.0 standard deviation from the means were removed, however, the models did not change in a significant manner. For the cash flow measures, the two-sample t-test for equal means suggests that the samples of restating and non-restating firms are very different, indicating once again the importance of cash flow to net income in general and cash flows from operations in particular in assessing true financial performance. Given that the sign on DevART $\mathrm{t}_{\mathrm{t}-1}$ is positive, a unit increase in deviation from the industry average of the accounts receivable turnover increases the likelihood of restating. Additionally, given that the sign on $\mathrm{CFNI}_{\text {variability }}$ is negative, a unit increase in the cash flow to net income from year to year decreases the likelihood of a restatement.

The results and conclusions of the statistical models provide further evidence on the usefulness of ratio analysis as well as cash flows to assess a firm's real economic performance. As highlighted by previous research, the accounts receivable turnover and cash flow to net income trends can help predict a firm's future. Even though the return on assets and the net profit margin are not statistically significant, the accounts receivable turnover rate and the cash flow to net income show promise. A unit increase in the deviation from the industry average for the accounts receivable turnover ratio increases the likelihood of a restatement by 2.5 percent. Sometimes earnings are boosted artificially and sales are exaggerated, increasing the accounts receivable turnover to an unparalleled level (both a company's and an industry's). Moreover, everything else held constant, an increase in the operating cash flow to net income ratio decreases the likelihood of a restatement by approximately 2.2 percent. This means that restating firms are more likely to experience decreases in their cash flow to net income ratio in the years prior to restatement.

Table 1

Variable and Significance Levels for the Return on Assets and Accounts Receivable Turnover

\begin{tabular}{|c|c|c|c|}
\hline Variable & ROA $_{\text {variability }}$ & $\operatorname{DevROA}_{\mathrm{t}-1}$ & DevROA $_{t-2}$ \\
\hline Significance level & Insignificant & Insignificant & Insignificant \\
\hline Variable & $\mathrm{ART}_{\text {variability }}$ & $\operatorname{DevART}_{\mathrm{t}-1}$ & DevART $_{t-2}$ \\
\hline $\begin{array}{l}\text { Significance level } \\
\text { Marginal effect of a unit increase }\end{array}$ & Insignificant & $\begin{array}{c}\text { Significant at the } 5 \text { percent level } \\
2.5\end{array}$ & Insignificant \\
\hline
\end{tabular}


Table 2

Variable and Significance Levels for the Net Profit Margin and the Cash Flow to Net Income

\begin{tabular}{|c|c|c|c|}
\hline & & & \\
\hline Variable & $\mathrm{NPM}_{\text {variability }}$ & $\operatorname{DevNPM}_{\mathrm{t}-1}$ & $\operatorname{DevNPM}_{\mathrm{t}-2}$ \\
\hline Significance level & Insignificant & Insignificant & Insignificant \\
\hline Variable & $\mathrm{CFNI}_{\text {variability }}$ & $\operatorname{DevCFNI}_{\mathrm{t}-1}$ & $\operatorname{DevCFNI}_{\mathrm{t}-2}$ \\
\hline Significance level & $\begin{array}{c}\text { Significant at the } 1 \text { percent } \\
\text { level }\end{array}$ & $\begin{array}{c}\text { Significant at the } 10 \text { percent } \\
\text { level }\end{array}$ & $\begin{array}{c}\text { Significant at the } 10 \text { percent } \\
\text { level }\end{array}$ \\
\hline $\begin{array}{l}\text { Marginal effect of a unit } \\
\text { increase }\end{array}$ & -2.2 & 1.4 & -1.5 \\
\hline
\end{tabular}

Even though the findings of this study are important, the models used present some limitations. In fact, because the deviation from the industry average in both 2000 and 2001 and the variability of a given ratio between 2000 and 2001 are related, these variables might have affected the outcomes of the statistical regressions. The logit probability model itself presents some biases. Estimates of the logit model are highly sensitive to the range of data observed in the sample. By building four different probability models, we might have unintentionally altered the real effects of the some of the variables. However, even though the model might have failed to capture the exact marginal effects of the ROA, NPM, ART, and CFNI, we minimized the effects of collinearity. Given that we do not look at time series data and that the results of the logit model are very similar to the results of the linear probability model, our data are not subject to serial correlation or heteroskedasticity. With the sample size under 500, estimates of the logit probability model are inflated. The sample used in this study might have imposed further limitations on this study. Accordingly, we should be cautious with the way we interpret the results of this study. We looked only at restating firms in 2002 and at financial statements in 2000 and 2001, and future research might look at a bigger sample and more years.

\section{CONCLUSION}

This study has demonstrated that cash flow and financial ratios can be used to predict the likelihood of earnings restatement. The results of this study suggest that negative variation in cash flows from operating activities and significant positive deviation from the industry average of the accounts receivable turnover rate represent red flags for potential fraud. When accounting is done within the confines imposed by the governing accounting bodies, financial ratios should reflect the true economic performance of companies and provide a sound basis for investors' and creditors' decisions. When accounting standards are violated, markets become inefficient and investors are misled. Consequently, it is crucial to be able to predict future earnings through the use of cash flow and ratio analysis. Because the flexibility of accrual-based accounting provides managers with leeway, some changes could be needed to address the issue of earnings management. Statement readers would be well-advised to pay particular attention to the accounts receivable turnover and relationship of operating cash flows to net income in judging the economic reality behind the financial statements.

\section{AUTHOR INFORMATION}

Abdoulaye Dabo is a 2012 Colorado College graduate in Economics on whose senior thesis the current article is based. E-mail: abdoulaye.dabo@coloradocollege.edu

Judith Laux is a Gerald L. Schlessman Professor of Economics and Business who researches and teaches in the areas of accounting and finance. She would like to thank the Chapman Foundation for grant support for this project. E-mail: jlaux@coloradocollege.edu (Corresponding author)

\section{REFERENCES}

1. Albrecht, Steve W., Earl K. Stice and James D. Stice. 2008. Financial Accounting, 10 ${ }^{\text {th }}$ ed. Thomson South-Western Publishers.

2. Aquino, Simona. 2010. "Accounting Indicators for Credit Risk Analysis of Firms: A Historical Perspective." Economia Aziendale Online. No. 2: 145-154.

3. Altman, Edward I. 1968. "Financial Ratios, Discriminant Analysis and the Prediction of Corporate Bankruptcy." Journal of Finance. Vol. 23, No.4: 589-609. 
4. Altman, Edward and Gabriele Sabato. 2007. "Modeling Credit Risk for SMEs. Evidence from the US Market.” ABA-CUS. Vol. 43, No.3: 332-357.

5. Altman, Edward, Gabriele Sabato and Nicholas Wilson. 2008. "The Value of Quantitative Information in SME Risk Management." Working Paper, Stern School of Business: 1-40.

6. Beaver, W. H. 1966. "Financial Ratios as Predictors of Failure." Supplement to Journal of Accounting Research. Vol. 4: 71-111.

7. Bergstresser, Daniel and Thomas Philippon. 2008. "CEO Incentives and Earnings Management." Journal of Financial Economics. Vol. 80: 511-29.

8. Bowen, Robert M, David Burgstahler, and Lane A. Daley. 1986. "Evidence on the Relationships Between Earnings and Various Measures of Cash Flow." Accounting Review. 61, No. 4: 713-725.

9. Davis, Harry and Yoram Peles. 1993. "Measuring Equilibrating Forces of Financial Ratios." Accounting Review. 68, no. 4: 725-747.

10. Dechow, Patricia and Douglas J. Skinner. 2000. "Earnings Management: Reconciling the Views of Accounting Academics, Practitioners, and Regulators." American Accounting Association. Vol. 14, No. 2: 235-250.

11. Fraser, Lyn M. and Aileen Ormiston. 2010. The Analysis of Financial Statements, $9^{\text {th }}$ ed. Upper Saddle River, NJ: Pearson/Prentice Hall.

12. Largay, James A. III and Clyde P. Stickney. 1980. "Cash Flows, Ratio Analysis and the W.T. Grant Company Bankruptcy." Financial Analysts Journal. 36, No. 4: 51-54.

13. Ohlson, J. A. 1980. "Financial Ratios and the Probabilistic Prediction of Bankruptcy." Journal of Accounting Research. Vol.19, No. 1: 109-131.

14. Qiang, Cheng and David Farber. 2008. "Earnings Restatements, Changes in CEO Compensation, and Firm Performance.” Working Paper, Sauder School of Business, January.

15. Richardson, Scott, Irem A. Tuna and Min Wu. 2002. "Predicting Earnings Management: The Case of Earnings Restatements.” Working Paper, London Business School, October: 1-41.

16. Sloan, R. G. 1996. "Do Stock Prices Fully Reflect Information in Accruals and Cash Flows About Future Earnings?" The Accounting Review 71: 289-315. 


\section{NOTES}

